\title{
Ozone as one of the factors affecting the safety of water supply
}

\author{
Józef Natonek ${ }^{1, *}$ \\ ${ }^{1}$ Jaworzno Waterworks Ltd, 43-600 Jaworzno, 34 Św. Wojciecha St, Poland
}

\begin{abstract}
Ozone, due to its strong oxidizing properties, is often used in high efficiency water treatment processes. It is not only used for water disinfection, but also for carboxylic acid, a product of its reaction, which highly contributes towards increasing biodegradability of organic substances in water, thus leading to higher quality of drinking water. This paper presents results of using mobile ozone devices as a way of local microorganisms elimination and sediments removal from WSS.
\end{abstract}

\section{Introduction}

Most waters intended for drinking by man that are taken in, both underground and surface waters, require more or less complex water treatment processes. One of such processes is oxidation, which is performed for many purposes, for instance [1-5]:

- removal of iron, manganese and nitrogen compounds from water,

- removal of hydrogen sulphide and sulphides from water,

- oxidation of compounds causing water to have colour, taste and odour,

- oxidation of micro-contaminations and natural organic matter,

- neutralisation of phytoplankton and zooplankton,

- facilitation of coagulation as a result of colloid destabilisation,

- disinfection of water.

Ozone, the reduction potential of which is $2.07 \mathrm{~V}$, plays a significant role in those processes. The key characteristic of ozone is its eco-friendly effect eliminating the formation of adverse oxidation byproducts generated in processes with use of chlorine compounds (chlorinated by-products). What is more, ozone disintegrates, coming back to pure oxygen, during ozonisation.

Due to its properties, ozone is commonly used in the treatment of water indented both for municipal and industrial purposes. In Poland, in 1959 - nearly 66 years after ozone was used in Dutch waterworks for the first time, ozone-based water disinfection was implemented in the waterworks of Kraków, in the Bielany water treatment plant. In practice, ozonisation is performed as the preliminary or intermediate oxidation process when using water supply systems. In those processes, ozonisation - being an advanced oxidation process - not only catalyses chemical reactions occurring in water, but it also - as a result of colloid depolarisation - supports the agglomeration of particles, and so increases the processing effectiveness of coagulation and filtration and decreases the dose of used coagulants by even $50 \%$. Moreover, in order to improve the safety of supplying water to consumers, ozone can be used to remove other contaminations such as phenols, detergents, pesticides, coordination complexes, pharmaceuticals or hormones. Apart from this, ozone is frequently the only and the most effective solution in processes of improving organoleptic characteristics of water, i.e. odour, taste or colour. Using ozone in water treatment contributes to reduction of applied chemical disinfectants considerably. Numerous studies $[6,7]$ show that in treatment processes, ozone allows obtaining biologically stable water, which is one of the requirements for the possibility to depart from chemical disinfection of water. All that we can achieve using ozone brings us closer to an eco-friendly water treatment system, where all chemical reagents are eliminated or minimised.

A significant use-related problem of water supply systems is widespread secondary water contamination when water is transported to the consumer $[8-11,12]$. The biofilm forming in the water pipes network is a considerable habitat of microorganisms, including pathogenic ones. In those circumstances, changing hydraulic conditions of use of water pipe network increase the risk of microbiological water contamination. This can be exemplified by a range of cases where biologically contaminated water, with coli group bacteria, Escherichia coli bacteria or Enterococcus faecalis bacteria, was supplied to consumers [11, 13-19]. The issue of microbiological contamination in water is often associated with the necessity to stop supplying water to the consumer or inform them about the fact that water is unfit for drinking. In such situations, water authorities must provide alternative water supply sources, identify the cause of contamination and take remedial action, such as flushing and disinfecting the water pipes network. 
Strong oxidation properties of ozone in a wide range of water reaction, short reaction time, no by-products detrimental to man and the environment, strong destructive properties in relation to pathogenic organisms and spores are qualities that allow this agent to be used in water supply system use operations. A significant part of this method is first and foremost short time required for effective disinfection of waterworks, which can translate into a considerably shorter time of water supply stoppage after its secondary biological contamination.

\section{Study subject}

Use of water pipes network as vast as that of Jaworzno is quite a challenge. In the city with the area of nearly 152 $\mathrm{km}^{2}$ and waterworks of total length of ca. $600 \mathrm{~km}$, a lot of conditions and factors decide whether water of proper quality is being supplied. Despite high quality of water pumped in waterworks, the aging, material-related and hydraulic structures have an effect on maintenance of physicochemical and microbiological stability of potable water when it is being supplied to the consumer. The Jaworzno waterworks is built of PE, PVC, cast iron and steel. The material diversity facilitates origination of many threats of deterioration of quality of water supplied to the consumer, for instance due to biofilm formation.

To increase the guarantee of high quality water supply and to ensure that water of stable parameters is supplied, MPWiK Sp. z o.o. in Jaworzno takes a range of actions aiming to improve water quality safety in the very waterworks. To that end, threats related to the following aspects are eliminated:

secondary water contamination in waterworks due to pipeline failure,

- proper disinfection of newly build waterworks sections before they are put into use,

- periodical disinfection of waterworks terminals with the longest water retention time.

If distributed water deteriorates in quality, particularly in terms of microbiology, a significant factor having an effect on the safety of water supplies in the system is the time needed to take and complete emergency action. The disinfection agents used so far (chlorine compounds) in the company have been effective, but they act for a long time (at least 1.5 day) and can be burdensome for the consumer. Therefore, in line with the policy of constantly improvement in quality of water supplied to Jaworzno inhabitants and in accordance with risk management procedures, an innovative and effective manner for water disinfection in waterworks lines, i.e. field supply system ozonisation, was implemented in the second half of 2016 in Jaworzno water supply system. Disinfection of water in the system with ozone considerably reduces the time of procedure (to several hours), and so increases consumer health safety and allows the waterworks infrastructure operator to remove chemical disinfection effects in the field as in the case of disinfection with traditional sodium hypochlorite.

\section{Principles of use of mobile waterworks flushing and disinfection system}

Mobile water ozonisation system "SPID" operates automatically. The nominal efficiency of the system is $1.5 \mathrm{~m}^{3} / \mathrm{h}$. The SPID ozonisation system is an assembly of technological unit elements providing the production of ozone (module for production of ozone from air in plasma blocks) in places of its application to the waterworks as well as an assembly of devices of a module for introducing ozone in water. Component parts of the modular assemblies of the mobile flushing and disinfection system SPID providing its effective operation in the field are as follows (Fig. 1):

oxygen production module - oxygen producer TOPAZ PLUS or ULTRA,

- ozone production ozone - one-module ozone generator, e.g. 1Z-WO60F-GT,

- water preparation module - two contact columns no. 1 and 2 ,

- module for introducing ozone in water: circulating pump PA, injector, ozone separator, quick stop valve $Z E 1$, static mixer,

- highly ozonised water pumping module,

- module for measurement of residual ozone in water - on-line measuring device KRYPTON NEON DES with feedback control,

- module for measurement of ozone in the air - online measuring device $\mathrm{K} 100 \mathrm{~W} \mathrm{GAS}$,

- destruction module with redundant ozone blowthrough.

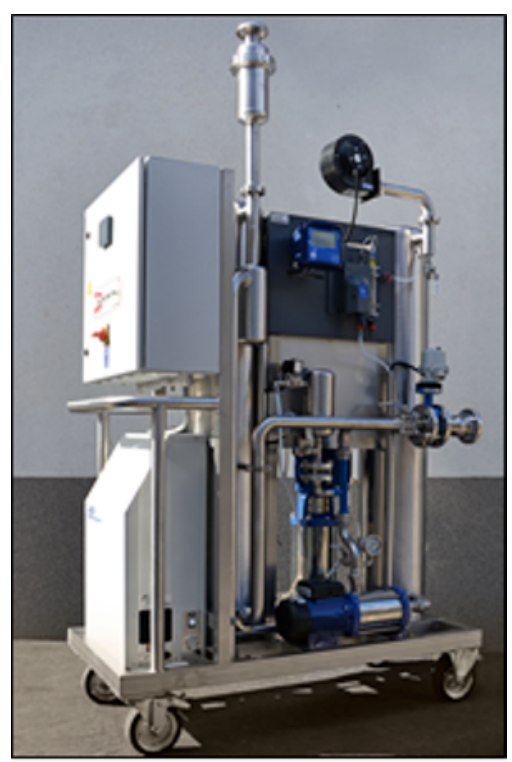

Fig. 1. LSPID - mobile system for flushing and disinfecting of water pipe network.

System of automatic control over operation of the mobile SPID device according to a strict configuration of individual unit processes allows a considerable reduction 
in the number of members of the operation-andrenovation team for operation of water supply system. After contact columns are filled with water, the valve allowing water to the ozonisation system closes automatically. Before the contact columns, a system for introducing ozone with the circulating pumps. Ozone is produced in the ozone generator out of the oxygen produced in the oxygen producer TOPAZ PLUS. The generated ozone is supplied by means of pressure to the ozone separator, equipped with safety measures protecting the ozone separator from flooding. The system for protecting the ozone generator from flooding is a three-degree protection system:

- Degree I - check valve in the injector,

- Degree II - check valve directly before the separator,

- Degree III - separator equipped with a conductometric probe cooperating with quick electric valve ZEO1 cutting off ozone supply.

The ozone from the separator is sucked under pressure by the injector as a result of water flowing through it. It is there that ozone is mixed with water from the second contact column, directed to individual component parts of the module for introducing ozone to water with circulating pump, for the first, preliminary time. The water, preliminarily ozonised in the injector, is pumped into the conduit feeding contact column no. 1, where it is thoroughly mixed with raw water in the static mixer. In the contact columns, water is saturated with oxygen. In column no. 2, water is degassed as a result of desorption of ozone, which is discharged outside with a fan by the ozone destructor. After contact column no. 2, the water is pumped into a selected part of the water supply system to disinfect or flush it. The ozone content in water supplied to the waterworks for disinfection fluctuates, on average, from $0.5 \mathrm{mgO}_{3} / \mathrm{L}$ to $1.0 \mathrm{mgO}_{3} / \mathrm{L}$ or more, depending on the required effects in terms of maintenance and operation of the waterworks.

In order to obtain high effects of waterworks disinfection, each and every time the process duration is to be selected well, which is determined both by the diameter and length of the conduit. The dose of ozone is also determined by the residual ozone content in the stream of water flowing out of the system being disinfected at the optimal level of $0.2-0.3 \mathrm{mgO}_{3} / \mathrm{L}$.

\section{Study methods and discussion of results}

The effectiveness of the operation of the mobile SPID system in the water supply system of Jaworzno was assessed in the modular system in June 2016. The water was examined in accordance with the recommended analytical procedures:

- temperature - acc. to PB-54 edition 01/22.04.2009,

- general number of microorganisms at $22 \pm 2{ }^{\circ} \mathrm{C}$ after 72 hours - acc. to PN-EN ISO 6222:2004,

- Coli group bacteria - acc. to PN-EN ISO 93082:2014-06,

- Escherichia coli - acc. to PN-EN ISO 9308-2:201406 ,

- Enterococci - acc. to PN-EN ISO 7899-2:2004,

- Clostridium perfringens (along with spores) - acc. to PB-28 edition 02/11.01.2010,

- Pseudomonas aeruginosa - acc. to PB-29 Edition 01/20.03.2013,

- ozone - acc. to PB-27 Edition 01/17.01.2013,

- turbidity - acc. to PN-EN ISO 7027:2003, Point 6,

- $\quad$ iron - acc. to PB-05 Edition 01/25.03.2010,

- manganese - acc. to PB-06 Edition 01/25.03.2010,

- bromates - acc. to: PN-EN ISO 15061:2003.

The modular system was built of PE pipeline with the diameter of $63 \mathrm{~mm}$ and length of $150 \mathrm{~m}$. The system was filled with water from the local pond, which water was held in the system for two days in a sun-exposed place in order to obtain highly excessive microbiological quality in water (Table 1). After that time, the system was flushed and pipeline disinfection began by setting the starting ozone dose in the SPID device at ca. $0.3 \mathrm{mgO}_{3} / 1$. The disinfection effect was monitored for 4 hours, when microbiological parameters and residual ozone content were being measured in water samples. The studies showed that over the first 20 minutes from pumping the ozonised water in the contaminated system, considerable reduction in microbiological parameters was achieved, i.e. the overall number of organisms dropped by $75 \%$ at $22 \pm 2{ }^{\circ} \mathrm{C}$. After 72 hours, the overall number of organisms went down by $73 \%$ at $36 \pm 2^{\circ} \mathrm{C}$ and after 48 hours there was a $85 \%$ and $87 \%$ removal of Coli group bacteria and Escherichia coli bacteria, respectively.

Table 1. The microbiological parameters of water quality in the model system - research time 03.06.2016

\begin{tabular}{|c|c|c|c|c|c|c|c|c|}
\hline $\begin{array}{c}\text { Sample } \\
\text { time }\end{array}$ & Temp. & $\begin{array}{c}\text { Number of } \\
\text { micro- } \\
\text { organisms at } \\
22^{\circ} \mathrm{C} \text { after } \\
72 \text { hours }\end{array}$ & $\begin{array}{c}\text { Number of } \\
\text { micro- } \\
\text { organisms at } \\
36^{\circ} \mathrm{C} \text { after } \\
48 \text { hours }\end{array}$ & $\begin{array}{c}\text { Coli group } \\
\text { bacteria }\end{array}$ & $\begin{array}{c}\text { Escherichia } \\
\text { coli }\end{array}$ & Enterococci & $\begin{array}{c}\text { Clostridium } \\
\text { perfringens }\end{array}$ & $\begin{array}{c}\text { Pseudomonas } \\
\text { aeruginosa } \\
\text { Ozone }\end{array}$ \\
\hline & ${ }^{\circ} \mathrm{C}$ & $\mathrm{CFU} / \mathrm{mL}$ & $\mathrm{CFU} / \mathrm{mL}$ & $\mathrm{CFU} / 100 \mathrm{~mL}$ & $\mathrm{CFU} / 100 \mathrm{~mL}$ & $\mathrm{CFU} / 100 \mathrm{~mL}$ & $\mathrm{CFU} / 100 \mathrm{~mL}$ CFUL/100ml/L & $\mathrm{mg} \mathrm{O} / \mathrm{L}$ \\
\hline $09: 55$ & 16 & $>300$ & $>300$ & 88,5 & 88,5 & 0 & 0 & 0 \\
\hline $10: 14$ & 16 & 74 & 82 & 13,7 & 11,1 & 0 & 0 & 0 \\
\hline $10: 35$ & 16 & 4 & 2 & 0 & 0 & 0 & 0 & 0 \\
\hline $10: 50$ & 16 & 4 & 4 & 0 & 0 & 0 & 1 & 0 \\
\hline $11: 05$ & 16 & 0 & 6 & 0 & 0 & 0 & 0 & 0 \\
\hline $11: 35$ & 16 & 28 & 19 & 0 & 0 & 0 & 3 & 0 \\
\hline $11: 40$ & 16 & 16 & 0 & 0 & 0 & 0 & 0 & 0 \\
\hline $14: 00$ & 16 & 13 & 3 & 0 & 0 & 0 & 0 \\
\hline
\end{tabular}


After 40 minutes from the beginning to the end of the experiment, a stable effect of the process was achieved, characterised mostly by microbiological parameters of water quality at $0 \mathrm{CFU} / 100 \mathrm{~mL}$ (Table 1$)$. In obtained water samples only, the overall number of macroorganisms both at $22^{\circ} \mathrm{C}$ after 72 hours, and $36^{\circ} \mathrm{C}$ after 48 hours, was from several to over a dozen colony forming units.

\section{Conclusions}

Preliminary studies of the technological effect of mobile SPID device to flush and disinfect waterworks showed significant limitation of threats for the consumer when microbiological contamination occurs in the supplied water. The effect was achieved thanks to reducing the duration of disinfection and flushing by many times: compared to commonly used chlorine compounds, from several days (2-1.5 days) to several hours (2-4 h). Moreover, the studies showed that:

- the initial ozone content at ca. $2 \mathrm{mg} \mathrm{O} / \mathrm{L}$ with the flow of water at $2-3 \mathrm{~m}^{3} / \mathrm{h}$ allows obtaining the first disinfection effect already after 20 minutes in the operation of the system with no side effects of disinfection (no bromate formation),

- the method is fully accepted by the consumer (residual ozone in water is at $0.02 \mathrm{mgO}_{3} / \mathrm{L}$ ) and supervisory bodies such as Poviat Sanitary Inspectorates,

- ozone disintegrates to pure oxygen in $100 \%$ after the processes and the devices of technological infrastructure do not require another flushing.

\section{References}

1. A. Kowal, M. Świderska-Bróż, Oczyszczanie wody podstawy teoretyczne $i$ technologiczne, procesy $i$ urzadzenia (PWN, Warszawa 2007)

2. J. Nawrocki, Ochr. Sr. 27, (2005)

3. R. Broseus, et al., Water Res. 43, 18 (2009)

4. M.A. Oturan, J.J. Aaron, J. Critical Reviews Environ. Sci. Technol. 44, 23 (2014),

5. M. Pawlita-Posmyk, M. Wzorek, Chemik, 70, 10, (2016)

6. D. van der Kooij, et al. Distributing drinking water with a low of zero disinfectant residua, operational and biological aspect (UKWIR, London (2003)

7. P. Smeets, et al., Drinking Water Eng. Sci. 2, (2009)

8. I Zimoch, E. Łobos, Desalin. Water Treat. 52, (2014)

9. B. Kołwzan, Ochr. Sr. 33, 4 (2011)

10. J. Wingender, Int. J. Hyg. Environ. Health, 214, 6 (2011)

11. I. Zimoch, Ochr. Sr. 29, 4 (2007)

12. Bakterie $w$ wodzie (Accessed on 12.12.2014).

13. http://czestochowa.naszemiasto.pl/artykul/bakteriegrupy-coli-w-wodociagu-koniecpol-nie-pijcie-wody (Accessed on 19.11.2016)

14. http://www.dziennikpolski24.pl/artykul/3682072,ba kterie-w-wodzie,id,t.html(Accessed on 12.12.2014)

15. I. Zimoch, Ochr. Sr. 29, 3 (2007)
1. J. Boguniewicz-Zablocka, I. Klosok-Bazan, V. Naddeo, Environ. Sci. Pollut. Res. (2017) (doi: 10.1007/s11356-017-0608-8)

16. http://pssechrzanow.wsse.krakow.pl (Accessed on 03.09.2016)

17. https://gazetalubuska.pl (Accessed on 03.09.2016r.)

18. M. Bożym, I. Kłosok-Bazan, M. Wzorek, Pol. J. Environ. Stud. 27, 3 (2018)

19. M. Gono, M. Kyncl, R. Gono, I. Kłosok-Bazan, PE 11, 89 (2013) 